\title{
NILAI-NILAI KARAKTER DALAM PEMBELAJARAN KETERAMPILAN BERBICARA BAHASA INDONESIA PADA SISWA SMK
}

\author{
Supriyadi ${ }^{1)}$ dan Siti Nursia Salapa ${ }^{2)}$ \\ 1) Fakultas Bahasa dan Budaya Universitas Negeri Gorotalo \\ ${ }^{2}$ SMK Negeri 1 Gorontalo \\ e-mail: supriyadiung@yahoo.co.id
}

\begin{abstract}
Abstrak
Penelitian ini bertujuan mendeksripsikan nilai-nilai karakter dalam pembelajaran keterampilan berbicara. Subjek penelitian adalah 23 siswa kelas X A-3 SMKN 1 Bulango Utara, Kabupaten Gorontalo. Data yang diperoleh berupa hasil observasi proses pembelajaran, hasil wawancara, dan deskripsi hasil studi dokumen. Selanjutnya, data yang terkumpul dianalisis dengan model interaktif. Hasil penelitian menunjukkan bahwa proses pembelajaran keterampilan berbicara bahasa Indonesia di SMK Negeri 1 Bulango Utara belum sepenuhnya mengandung nilai-nilai berkarakter. Nilai-nilai karakter yang selalu muncul adalah jujur, bertanggung jawab, percaya diri, ingin tahu atau cinta ilmu, dan menghargai orang lain. Sementara itu, nilai-nilai karakter yang intensitas kemunculannya kurang dalam setiap pembelajaran adalah bernalar (berpikir logis, kritis, kreatif, dan inovatif), santun, dan disiplin. Hasil pembelajaran mencakup hal-hal berikut: (a) objektivitas pembicaraan, (b) kualitas isi pembicaraan, (c) sasaran atau arah pembicaraan, dan (d) gaya berbicara.
\end{abstract}

Kata kunci: keterampilan berbicara, nilai karakter, bahasa Indonesia, siswa SMK

\section{MORAL VALUES IN THE LEARNING OF INDONESIAN SPEAKING SKILLS AMONG VOCATIONAL HIGH SCHOOL STUDENTS}

\begin{abstract}
This study aims to describe moral values in the learning of speaking skills. The research subjects were 23 students of Grade X A-3 SMKN 1 Bulango Utara, Gorontalo Regency. The data were the results of observations on the learning process, interviews, and description of the document study. The data were analyzed by the interactive model. The results show that the learning process of Indonesian speaking skills at SMK Negeri 1 Bulango Utara has not fully emphasized moral values. The values that always come up are honesty, responsibity, confidence, curiousity or love of science, and respect for others. Meanwhile, the values that rarely appear in learning are reasoning (logical, critical, creative, and innovative thinking), politeness, and discipline. The learning outcomes include: (a) the conversation objectivity, (b) the quality of the conversation content, (c) the goal or the direction of the conversation, and (d) the speaking style.
\end{abstract}

Keywords: speaking skills, moral values, Indonesian, vocational high school students

\section{PENDAHULUAN}

Berbicara merupakan salah satu aspek keterampilan berbahasa yang diperoleh melalui latihan secara terus-menerus agar bisa menjadi terampil.Keterampilan berbicara perlu dikuasai oleh siswa di samping keterampilan menyimak, membaca, dan menulis karena keterampilan 
berbicara merupakan bentuk keterampilan yang bersifat produktif yang dapat digunakan untuk menyampaikan ide atau gagasan, harapan, perasaan, maupun keinginan secara langsung kepada pendengar dengan menggunakan bahasa sebagai medianya.

Dalam menyampaikan sejumlah gagasan tersebut diperlukan bahasa Indonesia yang santun agar orang lainberkenan mendengarkan isi pembicaraan. Penggunaan bahasa Indonesia yang santun dimaksudkan untuk memberikan nilai rasa dan nilai etika sehingga pendengar akan memberikan perhatian dan tidak merasa tersinggung dengan pembicaraan tersebut (Pranowo, 2012:2).

Kebanyakan orang berbicara sekedar mengucapkan kata-kata tanpa memperhatikan keterpahaman pendengar mengenai isi yang dibicarakannya. Hal itu tentu bertentangan dengan pendapat Musaba (2012:5) yang intinya bahwa berbicara bukan hanya mampu mengemukakan apa yang ingin disampaikan, tetapi dapat menelaah dan memastikan bahwa apa yang disampaikan itu dapat diterima oleh pendengar atau lawan bicara.

Pada saat berbicara diperlukan kontrol emosi. Menyampaikan sesuatu dalam suasana sedih, marah, kecewa, senang, dan sebagainya akan mempengaruhi penggunaan bahasa (Indonesia) maupun sikap seseorang ketika berbicara di depan umum, dalam forum ilmiah, maupun berbicara dalam situasi santai. Jika kontrol emosi diperhatikan dengan baik, maka akan dihasilkan pembicaraan yang baik pula.

Fauzi (2004:132) mengatakan bahwa berbicara terkait dengan karakter atau kepribadian seseorang. Karakter adalah watak, tabiat, akhlak, atau juga kepribadian seseorang yang terbentuk dari hasil internalisasi berbagai kebajikan yang diyakini dan mendasari cara pandang, berpikir, sikap, dan cara bertindak orang tersebut (Afandi, 2011:87). Karakter atau kepribadian akan tampak pada apa yang dikehendaki, dirasakan, dipikirkan, dibicarakan, dan diperbuatnya.Oleh sebab itu, perilaku yang menunjukkan karakter ketika berbicara perlu diperhatikan agar tercipta hubungan yang baik antara pembicara dan pendengar.

Sampai saat ini, pembentukan atau penanaman karakter di lingkungan pendidikan merupakan topik utama yang sedang disosialisasikan pemerintah agar diintegrasikan pada setiap matapelajaran yang diajarkan di sekolah. Guru membantu dalam membentuk watak peserta didik dengan cara memberikan keteladanan, cara berbicara atau menyampaikan materi yang baik, toleransi, dan berbagai hal yang terkaitnya (Zulnuraini, 2012:1).

Soedarsono (2008:23) mengatakan bahwa pembinaan watak atau karakter merupakan tugas utama pendidikan. Pembinaan watak atau karakter melalui penanaman nilai-nilai luhur agama, adat istiadat, atau bahkan yang lahir dari kata hati yang suci dan nurani yang jujur akan menimbulkan etika yang menjadikan manusia menjadi bijaksana karena dapat membedakan perbuatan baik dan perbuatan buruk (Syafi'ie, 2004:16).

Matapelajaran Bahasa Indonesia sebagai salah satu matapelajaran di Sekolah Menengah Kejuruan (SMK) pada aspek keterampilan berbicara dipandang tempat untuk menanamkan karakter kepada siswa agar siswa dapat menyampaikan sejumlah gagasan yang dimilikinya dengan etika yang baik. Dengan memiliki keterampilan berbicara bahasa Indonesia yang mengandung nilai-nilai karakter, siswa akan mampu menerapkan norma atau aturan-aturan yang telah diperoleh dalam pembelajaran keterampilan berbicara bahasa Indonesia ketika mereka akan kembali ke masyarakat. Norma atau aturan-aturan yang dimaksudkan tersebut berkaitan dengan nilai-nilai karakter, seperti jujur, bertanggung jawab, percaya diri, bernalar (berpikir logis, kritis, kreatif 
dan inovatif), ingin tahu atau cinta ilmu, santun, disiplin, dan menghargai karya atau prestasi orang lain.

Nilai-nilai karakter tersebut diharapkan dapat membentuk objektivitas pembicaraan, kualitas isi pembicaraan, sasaran atau arah pembicaraan, dan gaya siswa dalam berbicara bahasa Indonesia. Rupanya harapan tersebut belum sejalan dengan kenyataan yang ditemukan dan rasakan peneliti selama menjadi guru bahasa Indonesia di SMK. Siswa belum sepenuhnya memiliki keterampilan berbicara bahasa Indonesia yang berkarakter. Hal itu tampak pada proses dan hasil belajar yang dicapai siswa selama ini. Proses pembelajaran yang memunculkan interaksi antara siswa dan guru, interaksi antara siswa dan siswa, interaksi siswa dan materi pembelajaran, maupun interaksi siswa dan media pembelajaran pada kegiatan pendahuluan, kegiatan inti pembelajaran, dan kegiatan penutup belum begitu menampakkan penggunaan bahasa Indonesia yang berkarakter. Di sisi lain, hasil pembelajaran keterampilan berbicara siswa yang meliputi objektivitas berbicara, kualitas isi pembicaraan, sasaran atau arah pembicaraan, dan gaya berbicara juga belum terlalu menampakkan penggunaan bahasa Indonesia yang berkarakter.

Terkait dengan gaya berbicara seseorang yang di dalamnya termasuk siswa, King (2010:63) mengatakan bahwa seorang pembicara yang baik seharusnya memiliki gaya yang khas dan tidak terpengaruh oleh gaya orang lain, karena gaya tersebut mencirikan karakter pembicaranya. Pendapat tersebut memiliki makna bahwa seseorang yang berkarakter adalah seseorang yang memiliki gaya berbicara yang khas dan tidak meniru gaya berbicara orang lain.

Pendapat King (2010:63) tersebut sejalan dengan kenyataan bahwa gaya dan sikap seseorang yang dekat dengan kehidupan siswa ataupun tokoh yang diidolakan oleh siswa akan memberikan pengaruh cukup besar terhadap gaya dan sikap berbicara siswa sehari-hari. Gaya dan sikap tersebut dapat berupa gerak tubuh, ekspresi, kepercayaan diri, dan penggunaan bahasa yang meliputi pemilihan kata dan istilah. Gaya dan sikap siswa itulah yang sering muncul pada saat berlangsungnya proses pembelajaran keterampilan berbicara bahasa Indonesia berkarakter.

Realitas lain yang peneliti temukan di lapangan adalah mengenai distribusi porsi jam pelajaran bahasa Indonesia di SMK. Distribusi jam pelajaran bahasa Indonesia di SMK kelas X adalah 90 menit atau dua jam pelajaran dalam seminggu. Distribusi waktu tersebut relatif sedikit dan tidak sebanding dengan jumlah kompetensi dasaryang harus dibelajarkan kepada siswa dalam satu tahun. Hal itu diprediksi menjadi salah satu faktor penyebab yang mempengaruhi pembelajaran keterampilan berbicara bahasa Indonesia yang berkarakter pada siswa menjadi kurang berhasil. Waktu pertemuan yang relatifsedikit menjadikan siswa tidak maksimal memperoleh pembelajaran keterampilan berbicara bahasa Indonesia yang berkarakter sehingga keterampilan berbicara siswa menjadi kurang berkarakter.

Berdasarkan sejumlah realitas tersebut peneliti memandang perlu pembelajaran keterampilan berbicara bahasa Indonesia yang mengandung nilai-nilai karakter (selanjutnya disebut pembelajaran keterampilan berbicara bahasa Indonesia yang berkarakter) dilaksanakan di SMK. Hal itu selaras dengan visi SMK, yakni menyiapkan lulusan yang siap bekerja dengan keahlian masing-masing dengan memiliki keterampilan berbicara bahasa Indonesia yang berkarakter. Tujuannya adalah memudahkan lulusan memasuki lingkungan kerja dan mampu menyosialisasikan produktivitas dan kualitas kerjanyadi masyarakat. 
Sehubungan dengan itu, penelitian ini difokuskan pada (1) proses pembelajaran keterampilan berbicara bahasa Indonesiayang mengandung nilai-nilai karakter di SMK Negeri 1 Bulango Utara. Proses pembelajaran tersebut dapat dilihat dari interaksi antara siswa dan guru, interaksi antara siswa dan siswa, interaksi siswa dan materi pembelajaran, dan interaksi siswa dan media pembelajaran pada kegiatan pendahuluan, kegiatan inti, dan kegiatan penutup pembelajaran., (2) hasil pembelajaran keterampilan berbicara bahasa Indonesia yang mengandung nilai-nilai karakter yang dicapai siswa SMK Negeri 1 Bulango Utara. Hasil pembelajaran keterampilan berbicara bahasa Indonesia yang mengandung nilai-nilai karakter berkaitan dengan objektivitas pembicaraan, kualitas isi pembicaraan, sasaran atau arah pembicaraan, dan gaya berbicara siswa pada topik-topik yang dibicarakan, dan (3) faktor-faktor yang mempengaruhi pembelajaran keterampilan berbicara Bahasa Indonesia yang mengandung nilai-nilai karakter di SMK Negeri 1 Bulango Utara. Faktor-faktor yang mempengaruhi pembelajaran berupa faktor eksternal yang berkaitan dengan proses dan hasil pembelajaran dan faktor internal yang berkaitan dengan diri siswa sebagai subjek penelitianyang memiliki latar belakang keluarga, budaya, dan sosial.

Pembelajaran keterampilan berbicara yang berkarakter ini merupakan pembelajaran salah satu aspek keterampilan berbahasa Indonesia yang dilaksanakan pada semua jenjang pendidikan. Pembelajaran keterampilan berbicara bahasa Indonesia yang berkarakter dimaksudkan untuk membentuk perilaku berbicara dan mengembangkan keterampilan berbicara bahasa Indonesia siswa yang berazaskan pada nilai-nilai karakter bangsa. Karakter siswa pada hakikatnya dapat diamati dalam dua tahap, yakni proses pembela- jaran yang meliputi interaksi siswa, baik interaksi antara siswa dan guru, interaksi antara siswa dan siswa, interaksi siswa dan materi pembelajaran, dan interaksi siswa dan media pembelajaran.Di sisi lain, tahap hasil pembelajaran meliputi objektivitas pembicaraan, kualitas isi pembicaraan, sasaran/arah pembicaraan, dan gaya berbicara siswa.

Berdasarkan sejumlah nilai karakter yang telah dijelaskan oleh Kemendiknas, peneliti mengharapkan ada delapan nilai karakter yang muncul selama proses dan hasil pembelajaran keterampilan berbicara bahasa Indonesia yang berkarakter. Kedelapan nilai karakter tersebut adalah jujur, bertanggung jawab, percaya diri, bernalar (berpikir logis, kritis, kreatif, dan inovatif), ingin tahu atau cinta ilmu, santun, disiplin, dan menghargai karya atau prestasi orang lain.

Pelaksanaan proses pembelajaran keterampilan berbicara bahasa Indonesia yang berkarakter tentu tidak terlepas dari penyusunan perencanaan pembelajaran yang dirancang oleh guru, seperti silabus, Rencana Pelaksanaan Pembelajaran (RPP), materi atau bahan ajar, media pembelajaran, perangkat evaluasi, dan panduan pembelajaran. Wahyuni dan Ibrahim (2012:11) berpendapat bahwa perencanaan pembelajaran merupakan bagian penting dalam pelaksanaan pendidikan di sekolah dan guru harus memiliki kemampuan membuat perencanaan pembelajaran. Dari pendapat tersebut dapat disimpulkan bahwa dalam mewujudkan pembelajaran keterampilan berbicara bahasa Indonesia yang berkarakter dibutuhkan sejumlah elemen yang saling menunjang satu dengan lainnya. Sejumlah elemen tersebut adalah kondisi belajar siswa, kompetensi guru dalam menyampaikan pembelajaran, dan perencanaan pembelajaran yang diintegrasikan dengan kedelapan nilai karakter. 


\section{METODE}

Penelitian ini dilaksanakan di SMK Negeri 1 Bulango Utara, Kabupaten Gorontalo tahun pelajaran 2012/2013. Sekolah tersebut merupakan sekolah paling diminati oleh siswa sejak diresmikan pada tahun 2005. Sekolah tersebut memiliki empat jurusan unggulan, yakni Agribisnis Tanaman Pangan (ATP), Teknologi Hasil Pertanian (THP), Agribisnis Ternak Unggas (ATU), dan Teknik Komputer Jaringan (TKJ). Jenis penelitian ini adalah deskriptif eksploratif. Peneliti berusaha mengeksplorasi proses pembelajaran keterampilan berbicara bahasa Indonesia yang berkarakter pada siswa SMK Negeri 1 Bulango Utara. Subjek penelitian ini adalah siswa kelas X A-3 yang berjumlah 23 siswa yang sampelnya diambil dengan teknik purposive random sampling.

Data penelitian bersumber dari siswa dan guru mata pelajaran Bahasa Indonesia, proses dan hasil pembelajaran keterampilan berbicara bahasa Indonesia yang berkarakter, dan perencanaan pembelajaran keterampilan berbicara bahasa Indonesia yang berkarakter. Instrumen penelitian yang digunakan adalah peneliti sebagai instrumen utama dan dibantu dengan catatan lapangan, panduan observasi, dan panduan wawancara. Teknik yang digunakan untuk mengumpulkan data adalah observasi, wawancara, dan studi dokumen. Data yang diperoleh berupa deskripsi hasil observasi selama proses pembelajaran, deskripsi hasil wawancara dengan guru, dan deskripsi hasil studi dokumen yang terdapat pada silabus, rencana pelaksanaan pembelajaran, materi ajar, media, dan perangkat evaluasi.

Selanjutnya, data yang terkumpul dianalisis dengan model interaktif dari Miles dan Huberman (2011:337). Berdasarkan model interaktif, langkah-langkah dalam menganalisis data adalahsebagai berikut (1) setelah data terkumpul melalui teknik observasi, wawancara, dan studi dokumentasi,dilakukan reduksi data, (2) menyusun data secara sistematis berdasarkan kategori dan klasifikasi tertentu, (3) membuat paparan data, yakni penyajian data dalam bentuk uraian singkat, bagan atau tabel, hubungan antarkategori, dan sejenisnya,(4) melakukan analisis silang atau cross site analysis terhadap data yang telah dipaparkan dengan cara membandingkan dan menganalisisnya secara mendalam, dan terakhir (5) menyajikan temuan, menarik simpulan, dan melaporkannya dalam bentuk laporan penelitian.

\section{HASIL DAN PEMBAHASAN}

Proses pembelajaran keterampilan berbicara bahasa Indonesia yang berkarakter di SMK Negeri 1 Bulango Utara secara umum berlangsung dalam tiga tahap kegiatan pembelajaran, yakni kegiatan pendahuluan, kegiatan inti, dan kegiatan penutup pembelajaran. Setiap kompetensi dasar yang dibelajarkan memunculkan interaksi siswa dalam proses pembelajaran secara beragam.Interaksi dalam proses pembelajaran keterampilan berbicara bahasa Indonesia di SMK Negeri 1 Bulango Utara dipaparkan berikut.

\section{Nilai-nilai Karakter dalam Proses Pem- belajaran pada Kompetensi Dasar 1}

Pada proses pembelajaran pada KD 1 siswa dibelajarkan "Melafalkan Kata dengan Artikulasi yang Tepat". Penggalan RPP-nya dapat dilihat pada Tabel 1.

Berdasarkan indikator pada tabel 1 di atas tujuan pembelajaran pada kompetensi dasar ini adalah mengharapkan siswa mampu memahami dan melafalkan kata-kata dengan artikulasi yang tepat. Kata-kata yang dilafalkan oleh siswa adalah kata-kata dalam bidang pertanian. Hal ini disesuaikan dengan jurusan kelas XA-3, yakni Agribisnis Tanaman Pangan (ATP), agar tercipta pembelajaran yang kontekstual. 
Tabel 1. Penggalan Rencana Pembelajaran KD 1

\begin{tabular}{|c|c|c|c|}
\hline $\begin{array}{c}\text { Standar } \\
\text { Kompetensi }\end{array}$ & $\begin{array}{c}\text { Kompetensi } \\
\text { Dasar }\end{array}$ & $\begin{array}{c}\text { Materi } \\
\text { Pembelajaran }\end{array}$ & Indikator \\
\hline $\begin{array}{l}\text { Berkomunikasi } \\
\text { dengan Bahasa } \\
\text { Indonesia } \\
\text { Setara Tingkat } \\
\text { Semenjana }\end{array}$ & $\begin{array}{l}\text { Melafalkan kata } \\
\text { dengan artikulasi } \\
\text { yang tepat }\end{array}$ & $\begin{array}{l}\text { - Cara melafalkan } \\
\text { kata dengan } \\
\text { suara yang jelas, } \\
\text { tekanan, dan } \\
\text { artikulasi yang } \\
\text { tepat. } \\
\text { - Kata-kata dalam } \\
\text { bidang pertanian. }\end{array}$ & $\begin{array}{l}\text { - Memahami cara } \\
\text { melafalkan kata dengan } \\
\text { suara yang jelas, tekanan, } \\
\text { dan artikulasi yang tepat } \\
\text { - Melafalkan kata-kata } \\
\text { dalam bidang pertanian } \\
\text { dengan suara yang jelas, } \\
\text { tekanan, dan artikulasi } \\
\text { yang tepat di depan kelas } \\
\text { secara individu } \\
\text { Nilai karakter: } \\
\text { Disiplin, percaya diri, } \\
\text { ingin tahu/cinta ilmu, dan } \\
\text { bertanggung jawab. }\end{array}$ \\
\hline
\end{tabular}

Dalam proses pembelajaran terjadi beberapa interaksi, baik interaksi antara siswa dengan guru, interaksi antara siswa dengan siswa, interaksi antara siswa dengan materi pembelajaran, maupun interaksi antara siswa dengan media pembelajaran. Kutipan interaksi selama proses pembelajaran tersebut dapat dilihat pada kegiatan pendahuluan, kegiatan inti pembelajaran, dan kegiatan penutup berikut.

\section{Kegiatan Pendahuluan}

Sebelum memulai kegiatan inti pembelajaran, guru melakukan apersepsi untuk menggali pengetahuan siswa tentang hal-hal yang berhubungan dengan Kompetensi Dasar dan materi yang akan dibelajarkan kepada siswa. Interaksi yang terjadi pada kegiatan pendahuluan ini dapat dilihat dalam kutipan berikut.

Guru : "Anak-anak, pernahkah kalian mengalami ketika berbicara dengan teman atau orang lain, terjadi salah paham?"

Siswa : "Pernah, bu" (menjawab serempak)

Guru : "Ada yang bisa mencontohkan salah paham yang bagaimana yang pernah dialami?"
Siswa $_{10}$ : "Saya pernah, ibu. Waktu itu saya bilang pa saya pe taman kalau saya ragu mo datangke rumahnya karena tidak tau alamatnya. Pas so hari rabu dia tunggu-tunggu saya tidak datang, ternyata dia mengira saya bilang ragu itu rabu."

Guru : "Ya, ada yang tau penyebab kesalah pahaman itu?"

Siswa $_{12}$ : "Salah dengar"

Siswa $_{3}$ : "Pongo nga pe taman itu stau. Haha (mungkin temanmu itu tuli, haha)"

Siswa $_{7}$ : "Ibu, bisa juga karena cara ba ucapraguhampir sama denganrabu."

Guru : "Itulah yang disebut dengan pengucapan atau pelafalan."

Kutipan di atas dapat dinyatakan bahwaterdapat beberapa macam interaksi siswa yang terjadi selama kegiatan pendahuluan berlangsung, yakni interaksi dengan guru dan interaksi dengan sesama siswa. Dalam interaksi tersebut meliputi perkataan-perkataan siswa yang mencerminkan nilai-nilai karakter, seperti Siswa ${ }_{10}$ yang segera memberikan contoh kasus mengenai kesalahpahaman dalam pengucapan/pelafalan kata (nilai percaya 
diri dan bertanggung jawab) berdasarkan pengalamannya (nilai jujur), Siswa yang memberikan pikiran banding (nilai bernalar), dan Siswa ${ }_{12}$ yang serius memperhatikan penjelasan guru sehingga ia langsung dapat menjawab pertanyaan yang diberikan (nilai cinta ilmu). Selain itu, ada juga Siswa ${ }_{3}$ yang menertawakan jawaban teman dengan menggunakan bahasa yang tidak wajar ketika berbicara. Sikap tersebut tidak mencirikan nilai karakter, seperti menghargai orang lain dan santun.

\section{Kegiatan Inti Pembelajaran}

Pada kegiatan inti pembelajaran, guru melakukan tiga tahap, yakni eksplorasi, elaborasi, dan konfirmasi. Interaksi pada ketiga tahap tersebut dapat dilihat dalam kutipan berikut.

Guru : "Anak-anak, seperti yang sudah dicontohkan tadi, kesalah pahaman dalam berbicara bisa disebabkan pelafalan kata atau kalimat yang tidak tepat. Hal ini tentu saja dipengaruhi oleh beberapa faktor. Ada yang tau?"

Siswa $_{3}$ : "Faktor pendengaran, ibu."

Guru : "Ya, apa lagi?"

Siswa $_{10}$ : "Kecepatan berbicara."

Guru : "Apa ketika kamu mengungucapkan kata itu terlalu cepat, Muhlis?"

Siswa $_{10}$ : "Iya, bu."

Guru : "Nah, terlalu cepat berbicara juga dapat menyebabkan pelafalan kata menjadi tidak tepat, ya."

Siswa $_{5}$ : "Ibu, ada olo yang depe ba bicara tidak normal, bisa mempengaruhi juga. (Ibu, ada juga yang bicaranya tidak normal, bisa mempengaruhi juga)."

Siswa $_{14}$ : "Apa nga punya ini, pa'?. Orang wowo so jelas-jelas tidak bisa bicara. (Apa maksud perkataanmu? Tuna rungu sudah pasti tidak bisa berbicara)."
Siswa $_{5}$ : “Maksudnya bukan wowo, tapi kayak cadel, tidak tau bilang huruf /r/. (maksudnya bukan tuna rungu, tapi seperti cadel yang tidak dapat mengucapkan huruf $/ \mathrm{r} /)^{\prime \prime}$

Siswa $_{2}$ : "Jang jaga ba singgung orang uti (Jangan suka menyinggung orang)."

Siswa $_{5}$ : "Ya Allah, bukan ba singgung kita, uti, hanya ba kase contoh. (Ya Allah, saya tidak bermaksud menyinggung, hanya memberikan contoh)"

Guru : "Iya, benar. Cadel juga bisa mempengaruhi pelafalan. Bisa diberikan contoh pelafalan kata bagi yang cadel sehingga dapat mengubah arti dari kalimat yang disampaikan? Coba Faiz!"

Siswa $_{4}$ : "Merambat dilafalkan melambat, bu. Kalau kalimatnya: Tanaman sirih tumbuh melambat. Seharusnya tumbuh merambat."

Guru : "Ya, bagus. Jadi bukan berarti menghina atau menyindir, ya. Kita belajar melihat keadaan yang sebenarnya. Orang yang cadel dapat mengatasi hal tersebut dengan memperlambat tempo pembicaraannya."

Siswa : "Ya, bu."

Guru : "Baiklah, sekarang ibu akan bagikan kertas ini. Di dalamnya tertulis jenis-jenis pupuk. Tugas kalian adalah melafalkannya sesuai dengan tekanan dan artikulasi yang tepat."

Kutipan di atas menunjukkan bahwa pada kegiatan inti pembelajaran ini terdapat beberapa macam interaksi siswa, baik interaksi dengan guru, interaksi dengan sesama siswa, dan interaksi dengan materi pembelajaran (lihat tabel 1). Dalam interaksi tersebut, perkataan-perkataan siswa yang mencerminkan nilai-nilai karakter selama kegiatan inti pembelajaran ini,

Nilai-nilai Karakter dalam Pembelajaran Ketrampilan Berbicara Bahasa Indonesia pada Siswa SMK 
seperti Siswa ${ }_{3}$ yang memberikan jawaban atas pertanyaan guru (nilai cinta ilmu), Siswa $_{10}$ yang mengakui bahwa kesalahpahaman pembicaraan dengan temannya disebabkan oleh cara ia berbicara (nilai jujur), Siswa ${ }_{5}$ yang memberikan pikiran banding (nilai bernalar, disiplin, dan cinta ilmu), dan Siswa ${ }_{4}$ yang diminta oleh guru untuk memberikan contoh pelafalan yang dapat mengubah makna (nilai bertanggung jawab). Selain itu, ada juga Siswa ${ }_{14}$ yang memotong/menyela pembicaraan untuk memprotes jawaban teman dengan menggunakan bahasa yang tidak wajar, serta Siswa ${ }_{2}$ yang menuduh/menganggap bahwa jawaban yang diberikan temannya adalah bersifat menyinggung. Sikap tersebut tidak mencirikan nilai karakter, seperti menghargai karya/prestasi orang lain, bernalar (berpikir logis, kritis, kreatif, dan inovatif), dan santun.

\section{Kegiatan Penutup}

Pada kegiatan penutup, guru merefleksi kegiatan pembelajaran dengan cara meminta siswa menyimpulkan hal-hal yang telah dipelajari. Bentuk interaksi yang terjadi pada kegiatan ini dapat dilihat dalam kutipan berikut.

Guru : "Baiklah, sebelum menutup pembelajaran hari ini, coba siapa yang dapat mengulang kembali materi yang telah dipelajari tadi?"

Siswa $_{10}$ : "Saya, bu."

Guru : "Coba yang lain dulu, ibu mau dengar suara dari yang lain.
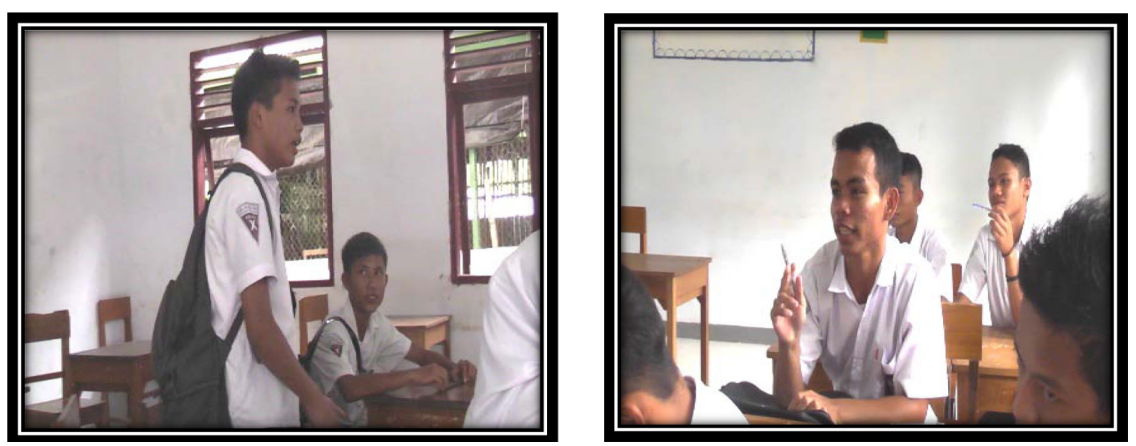

Gambar 1. Bentuk Interaksi Siswa pada Proses Pembelajaran KD 1
Coba Helda, apa saja yang sudah kita bahas tadi?"

Siswa $_{6}:$ "Tentang pelafalan kata yang sesuai dengan tekanan dan artikulasi yang tepat."

Guru : "Ya, bagus. Jangan malu-malu, ya. Coba Riski."

Siswa ${ }_{15}$ : "Sama, ibu."

Guru : "Sama apa maksudnya?"

Siswa ${ }_{15}$ : "Sama dengan Helda."

Guru : "Ya. Lain kali kalau diminta menyimpulkan materi harus bisa, ya. Jangan hanya bilang sama."

Interaksi tersebut dapat dianalisis bahwa bentuk interaksi yang terjadi pada kegiatan penutup ini adalah tanya jawab. Dalam interaksi tersebut muncul beberapa nilai karakter siswa, seperti Siswa ${ }_{10}$ yang segera menunjuk tangan untuk menjawab pertanyaan guru (nilai cinta ilmu) dan Siswa ${ }_{6}$ yang mau memberikan jawaban ketika guru memintanya (nilai bertanggung jawab). Selain itu, ada pula Siswa $_{15}$ yang tidak memberikan jawaban logis terhadap pertanyaan yang diberikan oleh guru. Sikap tersebut tidak mencirikan nilai karakter seperti bernalar (berpikir logis, kritis, kreatif, dan inovatif), percaya diri, dan ingin tahu atau cinta ilmu.

\section{Proses Pembelajaran pada Kompetensi Dasar2}

Pada proses pembelajaran ini siswa dibelajarkan mengenai Kompetensi Dasar "Memilih Kata, Bentuk Kata, dan Ungkapan yang Tepat". Penggalan Rencana 
pembelajarannya dapat dilihat dalam tabel 2.

Tujuan pembelajaran yang sesuai dengan indikator pembelajaran pada kompetensi dasar ini adalah mengharapkan siswa dapat menentukan topik paparan (uraian) singkat mengenai suatu hal/peristiwa/mekanisme kerja dengan pilihan kata, bentuk kata, dan ungkapan yang tepat dan mengkomunikasikannya dalam kegiatan diskusi.

Dalam proses pembelajaran terjadi beberapa interaksi, baik interaksi antara siswa dengan guru, interaksi antara siswa dengan siswa, interaksi antara siswa dengan materi pembelajaran, maupun interaksi antara siswa dengan media pembelajaran. Kutipan interaksi selama proses pembelajaran tersebut dapat dilihat pada kegiatan pendahuluan, kegiatan inti pembelajaran, dan kegiatan penutup berikut.

\section{Kegiatan Pendahuluan}

Sebelum memulai kegiatan inti pembelajaran, guru melakukan apersepsi untuk menggali pengetahuan siswa tentang hal-hal yang berhubungan dengan Kompetensi Dasar (KD) dan materi yang akan dibelajarkan kepada siswa. Interaksi yang terjadi pada kegiatan pendahuluan ini dapat dilihat dalam kutipan berikut.

Guru : "Anak-anak, Pak Hamid, wali kelas kalian, mengajarkan mata pelajaran produktif apa di kelas ini?"

Siswa : "Penyiapan Lahan, bu"

Guru : "Agar kalian dapat mempraktekkan dengan baik materi yang telah diajarkan, apa yang sebelumnya dilakukan oleh pak Hamid?"

Siswa ${ }_{12}$ : "Memberikan pengarahan, seperti bagaimana cara memilih lahan pertanian, cara memilih benih unggul. Macam-macam, bu."

Guru : "Nah, pernahkah pak Hamid menggunakan kata yang tidak kalian pahami dalam pengarahan itu?"

Siswa ${ }_{16}$ : "Pernah, ibu. Biasanya pak Hamid pake istilah-istilah yang baru torang dengar, kayak kompleksitas pupuk, pembuatan terasering (Pernah, ibu. Biasanya pak Hamid menggunakan istilah-istilah yang baru kami ketahui, seperti kompleksitas pupuk, pembuatan terasering)."

Tabel 2. Penggalan Rencana Pembelajaran KD 2

\begin{tabular}{|c|c|c|c|}
\hline $\begin{array}{c}\text { Standar } \\
\text { Kompetensi }\end{array}$ & $\begin{array}{c}\text { Kompetensi } \\
\text { Dasar }\end{array}$ & Materi & Indikator \\
\hline $\begin{array}{l}\text { Berkomunikasi } \\
\text { dengan Bahasa } \\
\text { Indonesia Setara } \\
\text { Tingkat Semenjana }\end{array}$ & $\begin{array}{l}\text { Memilih kata, } \\
\text { bentuk kata, dan } \\
\text { ungkapan yang } \\
\text { tepat. }\end{array}$ & $\begin{array}{l}\text { - Cara memilih } \\
\text { kata, bentuk kata, } \\
\text { dan ungkapan } \\
\text { yang tepat. } \\
\text { - Menyampaikan } \\
\text { sebuah paparan } \\
\text { (uraian) singkat. }\end{array}$ & $\begin{array}{l}\text { - Menentukan topik } \\
\text { paparan (uraian) } \\
\text { singkat mengenai } \\
\text { suatu hal/peristiwa/ } \\
\text { mekanisme kerja } \\
\text { dengan pilihan kata, } \\
\text { bentuk kata, dan } \\
\text { ungkapan yang tepat. } \\
\text { - Mengkomunikasikan } \\
\text { hasil kerja kelompok } \\
\text { dalam kegiatan diskusi. } \\
\text { Nilai karakter: } \\
\text { Jujur, bertanggung } \\
\text { jawab, ingin tahu/ cinta } \\
\text { ilmu, bernalar (berpikir } \\
\text { logis, kritis, kreatif, dan } \\
\text { inovatif), santun, dan } \\
\text { menghargai orang lain. }\end{array}$ \\
\hline
\end{tabular}

Nilai-nilai Karakter dalam Pembelajaran Ketrampilan Berbicara Bahasa Indonesia pada Siswa SMK 
Siswa $_{10}$ : "Vaksinasi tanaman, kontur lahan, penyemaian. Banyak ibu."

Siswa $_{7}$ : "Tapi pak Hamid mo jelaskan arti istilah itu. Ti pak bilang, sengaja diperkenalkan itu istilah supaya torang terbiasa menggunakannya. (Tapi pak Hamid akan menjelaskan arti dari istilah tersebut. Kata pak Hamid, istilah itu digunakan agar kami terbiasa menggunakannya)."

Guru : "Nah, sehubungan dengan itu, hari ini kita akan belajar bagaimana menyampaikan sebuah paparan singkat dengan pilihan kata, bentuk kata, dan ungkapan yang tepat."

Interaksi tersebut menunjukkan bahwa jenis tanya jawab dapat digunakan untuk memacing siswa berbicara dan mengeluarkan pendapatnya, seperti berani memberikan penjelasan terkait pertanyaan yang diberikan oleh guru. Situasi pada kegiatan ini cukup komunikatif, tetapi hanya beberapa siswa saja yang terlibat dalam interaksi tersebut, yakni Siswa $_{12^{\prime}}$, Siswa $_{16^{\prime}}$ Siswa $_{10}$, dan Siswa ${ }_{7}$. Sedangkan siswa yang lainnya terlihat lebih banyak menjawab pertanyaan guru secara bersamaan. Nilai karakter yang ditunjukkan oleh keempat siswa di atas adalah ingin tahu/cinta ilmu, jujur, percaya diri, bertanggung jawab, dan bernalar (berpikir logis, kritis, kreatif, dan inovatif). Di samping itu, ada beberapa siswa yang masih mencampur bahasa daerah dengan bahasa Indonesia ketika berbicara dengan guru.

\section{Kegiatan Inti Pembelajaran}

Pada kegiatan inti pembelajaran, guru melakukan tiga tahap, yakni eksplorasi, elaborasi, dan konfirmasi. Interaksi pada ketiga tahap tersebut dapat dilihat dalam kutipan berikut.

Guru : "Sehubungan dengan jawaban Iyam tadi, bagaimana cara memi- lih kata, bentuk kata, dan ungkapan yang tepat ketika menyampaikan sebuah paparan?"

Siswa : "Belum tau, ibu."

Guru : "Nah, kebetulan di tengah-tengah kita ada ibu Sitti yang sedang melakukan penelitian berkenaan dengan pembelajaran keterampilan berbicara, bagaimana kalau kita minta penjelasan dari beliau?"

Siswa : "Yaa..setuju"

$\mathrm{P}$ : "Baiklah, terima kasih telah memberikan kesempatan dan kepercayaan kepada saya untuk menjelaskan tentang penggunaan kata, bentuk kata, dan ungkapan yang tepat. Dalam menyampaikan sebuah paparan, terkadang seorang pembicara menggunakan kata-kata atau istilah tertentu. Tujuan penggunaan kata tersebut untuk memperkuat pernyataan yang diberikan atau kata tersebut memang berhubungan dengan topik yang disampaikan, seperti terasering, kontur, dan sebagainya yang digunakan oleh pak Hamid. Hal tersebut dilakukan, karena kata-kata tersebut memang berhubungan dengan mata pelajaran yang sedang diajarkan. Bisa dipahami?"

Siswa : "Yaa..bisa"

Guru : "Terima kasih penjelasannya, bu Sitti. Sekarang, tugas kalian adalah secara berkelompokmerumuskan sebuah bentuk paparan singkat tentang suatu hal/peristiwa/mekanisme kerja dengan memilih kata, bentuk kata, dan ungkapan yang tepat. Kemudian menyampaikannya secara lisan.

Bentuk interaksi pada kegiatan inti pembelajaran yang tampak dalam kutipan 
di atas tidak hanya antara siswa dengan guru dan interaksi antara siswa dengan materi pembelajaran, tetapi juga interaksi antara siswa dengan peneliti. Dalam interaksi tersebut, guru meminta peneliti memediasi siswa untuk lebih mendapatkan informasi dan pengetahuan mengenai materi yang sedang dibelajarkan.

Aktivitas siswa pada tahap ini cenderung pasif karena lebih banyak mendengarkan penjelasan materi, tetapi ketika guru membagi siswa ke dalam kelompok diskusi, siswa terlihat bersemangat dan interaksi yang terjadi antarsesama anggota kelompok punlebih aktif, demikian pula ketika diskusi antarkelompok berlangsung (lihat gambar 4.1.1b). Situasi tersebut mencirikan nilai-nilai karakter ingin tahu/cinta ilmu, bertanggung jawab, bernalar (berpikir logis, kritis, kreatif, dan inovatif), dan disiplin.

\section{Kegiatan Penutup}

Pada kegiatan penutup, guru melakukan refleksi dan menyampaikan rencana pembelajaran pada pertemuan berikutnya. Interaksi yang terjadi pada kegiatan ini dapat dilihat dalam kutipan berikut.

Guru : "Baiklah, setelah mengikuti pembelajaran tadi, manfaat apa yang dapat kalian peroleh daripokok bahasan kita hari ini?"

Siswa $_{5}$ : "Menjadi tahu cara menyampaikan paparan singkat dengan memilih kata, bentuk kata, dan ungkapan yang tepat."

Guru : "Ya, bagus. Ada pendapat yang lain?"

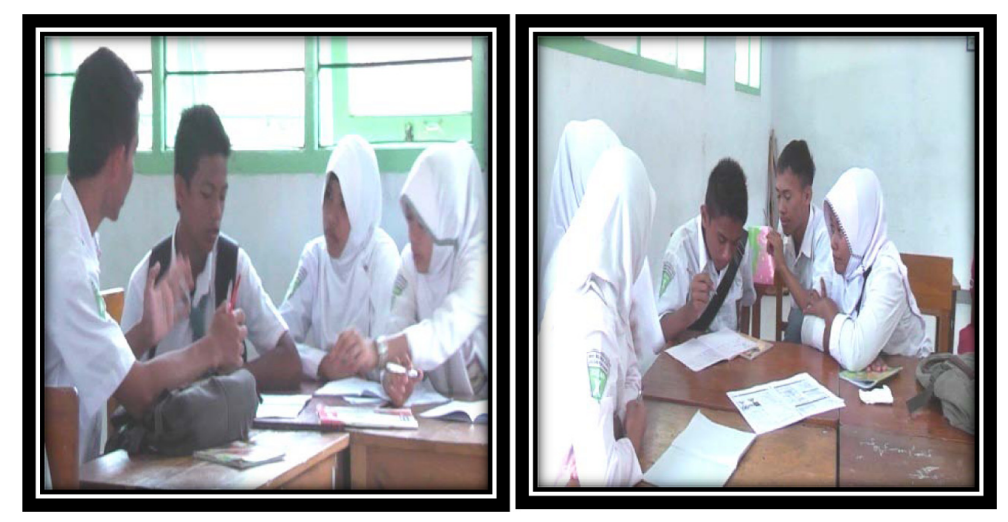

(A)

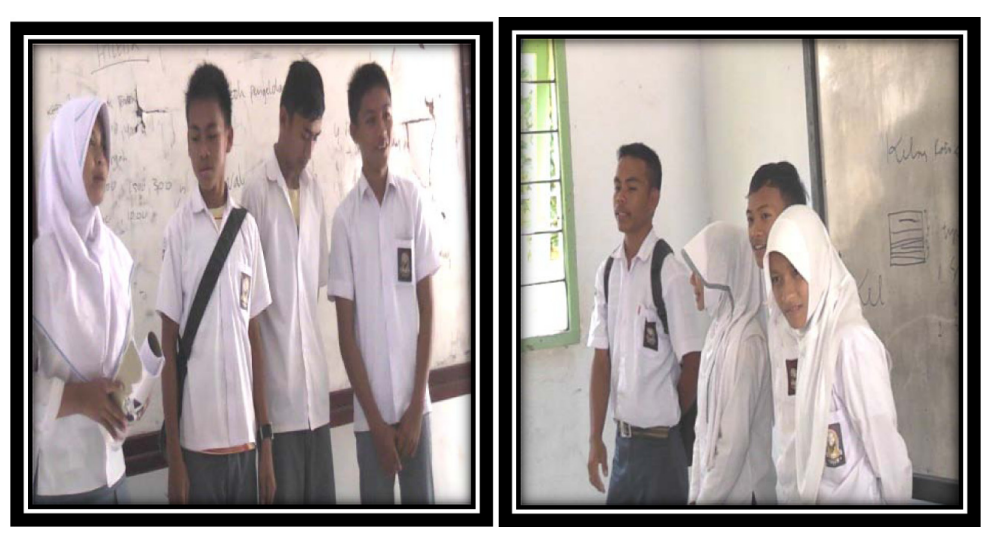

(B)

Gambar 2. Interaksi Antarsiswa dalam Kelompok Diskusi (A), Interaksi Antarkelompok Diskusi (B)

Nilai-nilai Karakter dalam Pembelajaran Ketrampilan Berbicara Bahasa Indonesia pada Siswa SMK 
Siswa : "Sama, bu."

Guru : "Baiklah, kalau hari ini kita belajar menyampaikan paparan singkat dengan memilih kata, bentuk kata, dan ungkapan yang tepat, maka pada pertemuan berikutnya kita akan belajar berdialog."

Refleksi yang dilakukan guru pada kegiatan penutup tersebutditunjukkan dalam bentuk interaksi tanya jawab. Dalam interaksi tersebut Siswa ${ }_{5}$ mewakili siswa yang lain untuk merefleksi pembelajaran. Nilai karakter yang tergambar dari tindakan Siswa ${ }_{5}$ adalah ingin tahu/ cinta ilmu, bertanggung jawab, santun, dan bernalar (berpikir logis, kritis, kreatif, dan inovatif).

\section{Proses Pembelajaran pada Kompetensi Dasar 3}

Pada proses pembelajaran ini siswa dibelajarkan mengenai Kompetensi Dasar "Menggunakan Kalimat yang Baik, Tepat, dan Santun". Penggalan rencana pembelajarannya dapat dilihat pada tabel 3.
Indikator pembelajaran pada kompetensi dasar di atas sesuai dengan tujuan pembelajaran, yakni mengharapkan siswa dapat mengidentifikasi kalimat yang komunikatif dilihat dari kaidah bahasa dan ketersampaian pesan, dapat membuat dialog, dan menampilkannya di depan kelas dengan pasangan masing-masing.

Dalam proses pembelajaran terjadi beberapa interaksi, baik interaksi antara siswa dengan guru, interaksi antara siswa dengan siswa, interaksi antara siswa dengan materi pembelajaran, dan interaksi antara siswa dengan media pembelajaran. Kutipan interaksi selama proses pembelajaran tersebut dapat dilihat pada kegiatan pendahuluan, kegiatan inti pembelajaran, dan kegiatan penutup berikut.

\section{Kegiatan Pendahuluan}

Sebelum memulai kegiatan inti pembelajaran, guru melakukan apersepsi untuk menggali pengetahuan siswa tentang hal-hal yang berhubungan dengan Kompetensi Dasar (KD) dan materi yang akan dibelajarkan kepada siswa. Interaksi yang terjadi pada kegiatan pendahuluan

Tabel 3. Penggalan Rencana Pembelajaran KD 3

\begin{tabular}{|c|c|c|c|}
\hline $\begin{array}{c}\text { Standar } \\
\text { Kompetensi }\end{array}$ & $\begin{array}{c}\text { Kompetensi } \\
\text { Dasar }\end{array}$ & Materi & Indikator \\
\hline $\begin{array}{l}\text { Berkomunikasi } \\
\text { dengan Bahasa } \\
\text { Indonesia Setara } \\
\text { Tingkat Semenjana }\end{array}$ & $\begin{array}{l}\text { Menggunakan } \\
\text { kalimat yang baik, } \\
\text { tepat, dan santun. }\end{array}$ & $\begin{array}{l}\text { - Syarat kalimat } \\
\text { efektif, } \\
\text { komunikatif, } \\
\text { dan santun. } \\
\text { - Berdialog. }\end{array}$ & $\begin{array}{l}\text { - Mengidentifikasi kalimat } \\
\text { komunikatif dan kalimat } \\
\text { tidak komunikatif dilihat } \\
\text { dari kaidah bahasa dan } \\
\text { ketersampaian pesan. } \\
\text { - Membuat dialog dengan } \\
\text { topik mempromosikan/ } \\
\text { menawarkan barang/jasa } \\
\text { dengan menggunakan } \\
\text { kalimat efektif, } \\
\text { komunikatif, dan santun } \\
\text { secara berpasangan. } \\
\text { - Berdialog di depan kelas. } \\
\text { Nilai karakter : } \\
\text { Jujur, percaya diri, } \\
\text { bertanggung jawab, } \\
\text { bernalar (berpikir logis, } \\
\text { kritis, kreatif, dan inovatif), } \\
\text { percaya diri, santun, dan } \\
\text { menghargai orang lain. }\end{array}$ \\
\hline
\end{tabular}

LITERA, Volume 16, Nomor 2, Oktober 2017 
ini dapat dilihat dalam kutipan berikut.

Guru : "Anak-anak, ibu ingin memperlihatkan sesuatu. Gambar apakah ini?"

Siswa $_{4}$ : "Orang yang sedang berbicara atau bercakap-cakap."

Siswa $_{9}$ : "Laki-laki dan perempuan yang sedang membicarakan sesuatu."

Siswa ${ }_{17}$ : "Orang yang berdialog."

Guru : "Bagus, semua jawaban benar. Kegiatan seperti ini sering kita temui, bahkan sekarang pun kita sedang melakukannya. Kegiatan dalam gambar ini disebut dengan berdialog."

Siswa $_{11}$ : "Tapi ibu, di gambar cuma dua orang sedangkan di kelas ini ada banyak orang. Sebenarnya berdialog itu harus berapa orang?"

Guru : "Bagus sekali pertanyaan dari Novita. Ada yang bisa menjawabnya?"

Siswa ${ }_{10}$ : "Kalau yang sering saya lihat di televisi, biasanya dialog itu ada dua orang atau lebih. Namanya saja dialog, berarti berbicara dengan orang lain, bisa dua orang atau lebih.

Guru : "Ya, bagus. Terima kasih atas jawabannya, Muhlis.Baiklah anak-anak, Kompetensi Dasar pada hari ini adalah Menggunakan Kalimat yang Baik, Tepat, dan Santun. Materi yang akan kita pelajari adalah berdialog dengan menggunakan kalimat yang efektif, komunikatif, dan santun."

Kutipan interaksi yang terjadi pada kegiatan pendahuluan di atas adalah berbentuk tanya jawab. Beberapa siswa mulai terlihat berani berinteraksi, bahkan ada yang mengajukan pertanyaan yang bersifat kritis. Peneliti menilai bahwa mulai ada kemajuan dalam proses interaksi siswa pada pembelajaran khususnya pada kompetensi dasar ketiga ini. Hal itu- menunjukkan pencerminan nilai karakter percaya diri, ingin tahu atau cinta ilmu, bertanggung jawab, dan bernalar.

\section{Kegiatan Inti Pembelajaran}

Pada kegiatan inti pembelajaran, guru melakukan tiga tahap, yakni eksplorasi, elaborasi, dan konfirmasi. Interaksi pada ketiga tahap tersebut dapat dilihat dalam kutipan berikut.

Guru : "Pada halaman 126 di buku Bahasa Indonesia yang telah kalian miliki, contoh dialog. Tugas kalian adalah membaca dialog tersebut dengan seksama. Perhatikan bahasa yang digunakan dan keterkaitan pembicaraan dengan topiknya. Waktu membaca selama 2 menit dan bisa dimulai sekarang.

Siswa : "Ya, bu."

Guru : "Baiklah, waktu 2 menit telah selesai. Yusri, topik apakah yang dibicarakan dalam dialog itu dan siapa saja tokoh-tokohnya?"

Siswa ${ }_{19}$ : "Topiknya tentang seorang penumpang yang sedang memesan tiket kereta api. Tokoh-tokohnya calon penumpang dan petugas loket, bu."

Guru : "Bagus. Sekarang Nangsi, bagaimanakah bahasa yang digunakan para tokoh dalam dialog tersebut dan apakah ada keterkaitan antara topik pembicaraan dengan pertanyaanpertanyaan dalam dialog?"

Siswa $_{9}$ : "Iya, ada keterkaitan. Bahasa yang digunakan adalah bahasa Indonesia yang baku dan sopan."

Guru : "Ya, bagus. Ini menandakan bahwa kalimatnya efektif, komunikatif, dan santun. Syarat sebuah kalimat dikatakan efektif, komunikatif, dan santun, jika pembicara dan lawan bicara melakukan interaksi dan pesan/

Nilai-nilai Karakter dalam Pembelajaran Ketrampilan Berbicara Bahasa Indonesia pada Siswa SMK 
maksud pembicaraan tersampaikan dengan baik. Bisa dipahami?"

Siswa : "Ya.."

Guru : "Nah, sekarang tugas kalian adalah membuat sebuah dialog singkat secara berpasangan, dengan topik mempromosikan atau menawarkan barang/jasa dengan menggunakan kalimat yang efektif, komunikatif, dan santun. Kemudian, menampilkannya di depan kelas dan akan dikomentari oleh teman lain."

Siswa $_{4}:$ "Ibu, dialognya dihafal atau boleh bawa buku?"

Guru : "Iya, jadi berdialognya secara lisan dan diusahakan untuk dihafal agar tidak membawa buku di depan. Baiklah, sekarang ibu berikan waktu 7 menit untuk membuatnya."

Dari kutipan di atas, terlihat bahwa usaha guru untuk mengaktifkan pembelajaran dengan memberikan pertanyaan-pertanyaan seputar dialog yang telah dibaca oleh siswa, cukup berhasil. Siswa dapat menjawab pertanyaan yang diberikan guru sehingga tercipta interaksi. Selain itu, menurut hasil pengamatan peneliti, sebagian besar siswa mampu berdialog di depan kelas tanpa membawa buku/catatan (lihat gambar 4.1.1c). Hal ini menunjukkan perilakuyang mencirikan nilai-nilai karakter, seperti ingin tahu/cinta ilmu, jujur, percaya diri, bertanggung jawab, bernalar, disiplin, dan menghargai karya/prestasi orang lain.

\section{Kegiatan Penutup}

Pada kegiatan penutup, guru merefleksi kegiatan pembelajaran dengan cara meminta siswa memberi penilaian terhadap proses pembelajaran yang telah dilakukan. Interaksi yang terjadi pada kegiatan ini dapat dilihat dalam kutipan berikut.

Guru : "Anak-anak, bagaimana tanggapan kalian mengenai pembelajaran hari ini?"

Siswa : "Baik, bu."

Guru : "Baik bagaimana maksudnya? Harus jelas dan disertai dengan alasan."

Siswa ${ }_{17}$ : "Asyik pembelajaran tadi, ibu. Kita jadi tau bagaimana caranya berdialog, karena teman-teman lain juga mengomentari isi dan penampilan."

Guru : "Ya, ada pendapat lain?"

Siswa $_{10}$ : "Jadi lebih berani kalau disuruh maju di depan kelas."

Siswa $_{4}$ : "Lain kali bikin bagini, ibu. Gaga, jadi semangat (lain kali pembelajarannya seperti ini. Bagus, jadi bersemangat)."

Guru : "Alhamdulillah, syukurlah kalau kalian merasa senang dengan pembelajaran hari ini. Ibu harap

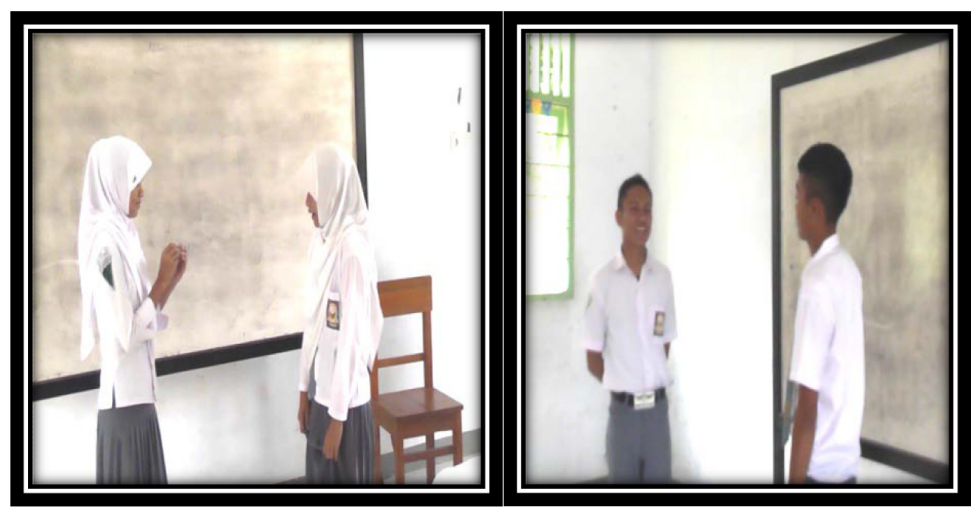

Gambar 3. Aktivitas Siswa Saat Berdialog di Depan Kelas 
materi berdialog hari ini dapat diterapkan dalam kehidupan sehari-hari, baik di sekolah dengan guru-guru, di rumah dengan orang tua, atau bersama temanteman."

Siswa : "Ya, bu."

Kegiatan refleksi yang tampak pada kutipan di atas menunjukkan kesenangan siswa terhadap materi yang dibelajarkan. Interaksi yang muncul lebih banyak mengungkapkan tentang pengalaman siswa mengikuti proses pembelajaran. Hal ini mencirikan nilai karakter jujur, bertanggung jawab, percaya diri, demokratis, dan ingin tahu atau cinta ilmu.
Berdasarkan data mengenai proses pembelajaran pada Kompetensi Dasar 1, 2, dan 3 di depan, intensitas kemunculan nilai-nilai karakter dalam interaksi siswa pada kegiatan pendahuluan, kegiatan inti pembelajaran, dan kegiatan penutup dapat dilihat pada tabel 4 .

Tabel 4 menunjukkan bahwa intensitas kemunculan nilai-nilai karakter selama proses pembelajaran pada Kompetensi Dasar I, II, III, dan IV belum maksimal seperti yang diharapkan, khususnya nilai karakter percaya diri, bernalar, santun, dan menghargai karya/prestasi orang lain.

Nilai kesantunan terkait dengan bahasa yang digunakan siswa ketika berbicara.

Tabel 4. Intensitas Kemunculan Nilai-nilai Karakter Selama Proses Pembelajaran Bahasa Indonesia

\begin{tabular}{|c|c|c|c|c|c|c|c|}
\hline \multirow{2}{*}{ No. } & \multirow{2}{*}{ Nilai Karakter } & \multicolumn{4}{|c|}{ Kompetensi Dasar (KD) } & \multirow{2}{*}{ Jumlah } & \multirow{2}{*}{ Ket. } \\
\hline & & I & II & III & IV & & \\
\hline \multirow[t]{3}{*}{1.} & Jujur & 2 & 1 & 2 & 2 & 7 & Pendahuluan $\quad: 2 x$ \\
\hline & & & & & & & Inti Pembelajaran: $2 x$ \\
\hline & & & & & & & Penutup $\quad: 2 x$ \\
\hline \multirow[t]{3}{*}{2.} & Bertanggung & 3 & 3 & 3 & 3 & 12 & Pendahuluan $: 3 x$ \\
\hline & Jawab & & & & & & Inti Pembelajaran: $3 x$ \\
\hline & & & & & & & Penutup $\quad: 3 x$ \\
\hline \multirow[t]{3}{*}{3.} & Percaya Diri & - & 3 & 3 & 3 & 6 & Pendahuluan $: 2 x$ \\
\hline & & & & & & & Inti Pembelajaran: $2 x$ \\
\hline & & & & & & & Penutup $\quad: 2 x$ \\
\hline \multirow[t]{3}{*}{4.} & Bernalar & 1 & 1 & 2 & 1 & 5 & Pendahuluan $\quad: 2 \mathrm{x}$ \\
\hline & & & & & & & Inti Pembelajaran: $1 x$ \\
\hline & & & & & & & Penutup $\quad: 1 \mathrm{x}$ \\
\hline \multirow[t]{3}{*}{5.} & Ingin Tahu & 3 & 3 & 3 & 3 & 12 & Pendahuluan $\quad: 3 x$ \\
\hline & atau Cinta & & & & & & Inti Pembelajaran: $3 x$ \\
\hline & Ilmu & & & & & & Penutup $\quad: 3 x$ \\
\hline \multirow[t]{3}{*}{6.} & Santun & - & 1 & - & 2 & 3 & Pendahuluan $\quad: 1 \mathrm{x}$ \\
\hline & & & & & & & Inti Pembelajaran: $1 x$ \\
\hline & & & & & & & Penutup $\quad: 1 \mathrm{x}$ \\
\hline \multirow[t]{3}{*}{7.} & Disiplin & - & 1 & 2 & 2 & 5 & Pendahuluan $\quad: 2 x$ \\
\hline & & & & & & & Inti Pembelajaran: $1 x$ \\
\hline & & & & & & & Penutup $\quad: 1 \mathrm{x}$ \\
\hline \multirow[t]{3}{*}{8.} & Menghargai & - & 3 & 2 & 3 & 8 & Pendahuluan $\quad: 2 x$ \\
\hline & Karya/Prestasi & & & & & & Inti Pembelajaran: $2 x$ \\
\hline & Orang Lain & & & & & & Penutup $\quad: 2 x$ \\
\hline
\end{tabular}

$\overline{\text { Nilai-nilai Karakter dalam Pembelajaran Ketrampilan Berbicara Bahasa Indonesia pada Siswa SMK }}$ 
Siswa belum dapat menempatkan bahasa yang digunakan saat berbicara dengan teman dan guru. Hal itu antara lain dipengaruhi oleh percampuran bahasa Indonesia dengan bahasa daerah yang digunakan siswa sehari-hari. Bernalar (berpikir logis, kritis, kreatif, dan inovatif), yakni berpikir dan melakukan sesuatu untuk menghasilkan cara atau hasil baru dari sesuatu yang telah ada atau dimiliki. Percaya diri terkait dengan perilaku siap melakukan sesuatu untuk menunjukkan kemampuan yang dimiliki atas dasar keberanian dan keterbukaan, sedangkan menghargai karya atau prestasi orang lain terkait sikap dan tindakan yang mendorong dirinya untuk menghasilkan sesuatu yang berguna bagi masyarakat, serta menghormati keberhasilan orang lain.

Interaksi yang terjalin antara siswa dengan guru pada saat proses pembelajaran tidak sekomunikatif interaksi antara siswa dengan siswa lain. Stubbsdan Moss (1996) mengatakan bahwa dalam banyak situasi kelas, interaksi verbal antara siswa dan guru digambarkan sebagai bentuk komunikasi yang sangat terbatas, bahkan sering kali berbeda dengan percakapan dalam interaksi sosial sehari-hari. Selanjutnya, Ghazali (2010:27) mengemukakan bahwa pembelajaran bahasa yang interaktif berfokus pada upaya untuk menciptakan situasi-situasi yang komunikatif dan memungkinkan siswa menyampaikan dan menerima pesan-pesan otentik yang mengandung informasi menarik bagi pendengar atau lawan bicara.

Penciptaan interaksi yang komunikatif pada kegiatan pendahuluan pembelajaran, tindakan yang dilakukan guru adalah dengan memberikan pertanyaanpertanyaan pancingan sebagai apersepsi atau luncuran awal yang diberikan kepada siswa. Hal itu menurut Yamin dan Ansari (2012:31-32) bertujuan merangsang siswa berpikir, yakni merangsang siswa menggunakan gagasan sendiri dalam menjawab dan bukan mengulangi gagasan yang telah disampaikan guru. Pertanyaan yang diberikan kepada siswa hendaknya memenuhi kategori berikut (a) terbuka, yakni pertanyaan yang memiliki lebih dari satu jawaban yang benar, (b) tertutup, yakni pertanyaan yang hanya memiliki satu jawaban yang benar, (c) produktif, yakni pertanyaan hanya dapat dijawab melalui pengamatan, percobaan, dan penyelidikan, (d) tidak produktif, yakni pertanyaan yang dapat dijawab hanya dengan melihat, tanpa melakukan pengamatan, percobaan, atau penyelidikan, (e) imajinatif, yakni interpretasi pertanyaan yang jawabannya di luar benda, gambar, kejadian yang diamati, dan (f) faktual, yakni pertanyaan yang jawabannya dapat dilihat pada benda atau kejadian yang diamati.

Keterlibatan berinteraksi siswa pada proses pembelajaran salah satunya karena dipengaruhi oleh kebiasaan dan kemauan atau keinginan mengungkapkan apa yang dipikirkan dan dirasakannya secara langsung. Sikap seperti itu memungkinkan seseorang menjadi pandai berbicara karena selalu mengambil kesempatan berbicara dalam setiap kegiatan, misalnya diskusi maupun kegiatan lainnya (Semi, 2008:6). Siswa yang aktif berinteraksi di kelas X-A3 hanyalah siswa tertentu saja, yakni siswa ${ }_{5^{\prime}}$ Siswa $_{10^{\prime}}$ siswa $_{12}$, dan siswa ${ }_{17}$.

Di sisi lain, terdapat keberagaman prilaku dan sikap siswa pada saat proses pembelajaran, di antaranya (a) siswa yang aktif berinteraksi, yaitu siswa yang umumnya selalu mendominasi setiap pembicaraan. Biasanya, siswa aktif pada saat guru bertanya atau meminta pendapat mengenai suatu masalah yang menjadi topik bahasan yang sedang dibelajarkan, (b) siswa yang tidak aktif berinteraksi, yaitu siswa yang tidak dan atau kurang aktif berinteraksi biasanya ditandai oleh adanya sikap diam ketika diminta menjawab pertanyaan, mengungkapkan ide atau gagasannya atau bertanya. Mulyana (2001:98-99) mengatakan bahwa prilaku 
tersebut disebabkan oleh beberapa kemungkinan, seperti rasa malu, segan, ragu-ragu, setuju, tidak peduli, marah atau tersinggung, atau sakit, dan (3) siswa yang hiperaktif, yaitu siswa yang berbicara tanpa didasari kelogisan ide, sehingga pembicaraannya menjadi tidak objektif dan cenderung mengganggu atau merusak konsentrasi kelas. Perilaku siswa tersebut berusaha menarik perhatian guru dan temannya dengan berbuat sesuatu yang aneh atau berbicara sesuai dengan kemauannya sendiri (Yamin dan Ansari, 2012:26-27).

Prilaku atau sikap-sikap siswa yang muncul pada saat berlangsungnya proses pembelajaran keterampilan berbicara bahasa Indonesia tersebut merupakan perwujudan dari nilai-nilai karakter. Kemunculan nilai-nilai karakter tersebut juga dapat ditemukan pada saat siswa berada di rumah hasil penanaman karakter oleh orang tua. Para orang tua juga menanamkan karakter anak melalui bahasa, seperti kejujuran, tanggung jawab, keberanian, saling menghormati, dan lain sebagainya (Kristiyani, 252-253). Dari delapan nilai karakter yang menjadi fokus penelitianterkait dengan keterampilan berbicara, yakni jujur, bertanggung jawab, ingin tahu atau cinta ilmu, santun, percaya diri, disiplin, bernalar (berpikir logis, kritis, kreatif, dan inovatif), dan menghargai orang lain, ditemukan ada tiga nilai karakter yang intensitas kemunculannya sangat kurang, yakni santun, percaya diri, dan disiplin.

Selanjutnya, untuk mengetahui hasil pembelajaran keterampilan berbicara bahasa Indonesia yang berkarakter, guru mengevaluasinya melalui kegiatan dialog yang ditampilkan siswa secara berpasangan di depan kelas. Dialog yang ditampilkan tersebut adalah dialog persuasif dengan tema yang telah ditentukan oleh guru, yakni "Mengajak/Mempromosikan/ Menawarkan Suatu Barang/Jasa".
Jenis penilaian yang dilakukan guru untuk mengevaluasi hasil pembelajaran adalah penilaian unjuk kerja. Penilaian tersebut paling objektif karena dilakukan dengan cara mengamati kegiatan siswa pada saat melakukan sesuatu (Wahyuni dan Ibrahim, 2012: 73). Penilaian tersebut mengandung prinsip-prinsip seperti yang dikemukakan oleh Tarigan (2008:28) berikut (a) ketepatan bunyi (vokal dan konsonan) yang diucapkan, (b) kesesuaian pola-pola intonasi, naik turunnya suara, serta tekanan suku kata, (c) keterpahaman pembicara terhadap bahasa yang digunakan melalui ketetapan dan ketepatan ucapannya, (4) ketepatan bentuk dan urutan kata-kata yang diucapkan, (5) kewajaran dan kelancaran berbicara, dan (6) kelaziman kata, keefektifan kalimat, dan kepercayaan diri ketika berbicara (Musaba, 2012: 123-126).

Hasil pembelajaran tersebut selanjutnya diolahdengan menggunakan instrumen skala nilai (rating scale), yaitu alat atau instrumen penilaian unjuk kerja yang memungkinkan guru memberikan nilai tengah terhadap penguasaan kompetensi tertentu, karena pemberian nilai secara kontinu yang memiliki pilihan kategori nilai lebih dari dua (Mohidin dan Yakob, 2011:23). Dari penilaian tersebut, ada empat hal pokok untuk mengetahui keterampilan berbicara bahasa Indonesia yang berkarakter. Pertama, objektifitas dalam berbicara. Objektivitas dalam berbicara terkait dengan bahasa yang digunakan. Siswa sering mencampur bahasa Indonesia dengan bahasa asing atau gaul tersebut dalam berbicara. Sebagian besar kata, bentuk kata, maupun ungkapan yang digunakan adalah bahasa asing atau gaul tanpa memperhatikan keterkaitan dan kejelasan maknanya. Sapir dan Worf (dalam Pranowo, 2012:26) mengatakan bahwa orang yang ketika berbicara menggunakan pilihan kata, ungkapan yang santun, dan kebenaran struktur kalimat menandakan kepribadian yang baik.

Nilai-nilai Karakter dalam Pembelajaran Ketrampilan Berbicara Bahasa Indonesia pada Siswa SMK 
Untuk menentukan watak, sifat, dan kepribadian seseorang dapat dilihat pada bahasanya.

Kedua, kualitas isi pembicaraan. Suatu pembicaraan yang baik adalah yang memperhatikan kualitas isi pembicaraannya. Namun, sering ditemukan adanya suatu pembicaraan yang tidak berkualitas. Hal ini menurut King (2010:78-81) dipengaruhi oleh adanya (a) penggunaan katakata yang muluk, yaitu kata-kata rumit yang digunakan sebagai simbol ucapan untuk mengesankan pendengar, (b) katakata trendi, yaitu kata-kata mutakhir atau catchphrases yang muncul pada masamasa tertentu. Penggunaan kata-kata trendi yang berlebihan akan membuat pembicaraan menjadi tidak orisinil dan terkesan klise, dan (c) kata-kata tanpa arti, yaitu tambahan kata yang penggunaannya dapat mengacaukan karena tidak ada keterkaitan arti/makna dengan inti pembicaraan.

Ketiga, sasaran atau arah pembicaraan. Suatu pembicaraan yang berkualitas ditunjang pula oleh ketepatan dan relevansi sasaran atau arah pembicaraan dengan topik yang sedang dibicarakan. Rothwell (dalam Devito, 1997:145-146) menjelaskan bahwa pesan atau isi pembicaran yang tidak terarah akan mempengaruhi keefektifan komunikasi. Akan tetapi, hal tersebut dapat diantisipasi dengan cara menghindari penggunaan kata-kata yang berbelitbelit, karena hanya akan membenamkan pesan ke dalam timbunan kata-kata.

Keempat, gaya berbicara. Gaya berbicara merupakan kunci sukses seorang pembicara untuk mengefektifkan pembicaraan (King, 2010:75). Selain itu, gaya berbicara erat pula kaitannya dengan komunikasi nonverbal, yaitu gerak-gerik dan ekspresi yang ditunjukkan saat berbicara.

Sehubungan dengan itu, terdapat empat hal pokok untuk mengetahui keterampilan berbicara bahasa Indonesia yang berkarakter. Pertama,objektivitas dalam berbicara. Objektivitas dalam berbicara terkait dengan bahasa yang digunakan. Siswa sering kali mencampur bahasa Indonesia dengan bahasa asing atau gaul dalam berbicara. Sebagian besar kata, bentuk kata, maupun ungkapan yang digunakan adalah bahasa asing atau gaul tanpa memperhatikan keterkaitan dan kejelasan maknanya. Sapir dan Worf (dalam Pranowo, 2012:26) mengatakan bahwa orang yang ketika berbicara menggunakan pilihan kata, ungkapan yang santun, dan kebenaran struktur kalimat menandakan kepribadian yang baik. Dalam menentukan watak, sifat, dan kepribadian seseorang dapat dilihat pada bahasanya. Kebiasaan menggunakan bahasa yang santun ketika berbicara akan turut mempengaruhi pembentukan karakter siswa, khususnya dalam pembelajaran bahasa Indonesia, karena kesantunan berbahasa Indonesia bukan hanya dapat menghaluskan pemakaian bahasa Indonesia, tetapi juga dapat menghaluskan budi dan prilaku pemakainya (Pranowo, 2012:31).

Kedua, kualitas isi pembicaraan. Suatu pembicaraan yang baik adalah yang memperhatikan kualitas isi pembicaraannya. Namun, seringkali ditemukan adanya suatu pembicaraan yang tidak berkualitas. Hal ini menurut King (2010:78-81) dipengaruhi oleh adanya (a) penggunaan kata-kata yang muluk, yaitu kata-kata rumit yang digunakan sebagai simbol ucapan untuk mengesankan pendengar, (b) kata-kata trendi, yaitu kata-kata mutakhir atau catchphrases yang muncul pada masamasa tertentu. Penggunaan kata-kata trendi yang berlebihan akan membuat pembicaraan menjadi tidak orisinil dan terkesan klise, dan (c) kata-kata tanpa arti, yaitu tambahan kata yang penggunaannya dapat mengacaukan karena tidak ada keterkaitan arti/makna dengan inti pembicaraan.

Ketiga, sasaran atau arah pembicaraan. Suatu pembicaraan yang berkualitas ditunjang pula oleh ketepatan dan relevansi 
sasaran atau arah pembicaraan dengan topik yang sedang dibicarakan. Rothwell (dalam Devito, 1997:145-146) menjelaskan bahwa pesan atau isi pembicaran yang tidak terarah akan mempengaruhi keefektifan komunikasi. Akan tetapi, hal tersebut dapat diantisipasi dengan cara menghindari penggunaan kata yang berbelit-belit, karena hanya akan membenamkan pesan ke dalam timbunan kata-kata.

Keempat, gaya berbicara. Gaya berbicara merupakan kunci sukses seorang pembicara untuk mengefektifkan pembicaraan (King, 2010:75). Selain itu, gaya berbicara erat pula kaitannya dengan komunikasi nonverbal, yaitu gerak-gerik dan ekspresi yang ditunjukkan saat berbicara. Komunikasi nonverbal berfungsi untuk (a) menekankan beberapa bagian dari pesan verbal yang disampaikan, (b) melengkapi sikap ketika berbicara, misalnya dengan memperlihatkan ekspresi atau mimik wajah ataupun gerakan anggota tubuh lainnya, dan (3) mengulangi atau merumuskan kembali makna dari pesan verbal yang telah disampaikan.

Selaras dengan temuan penelitian ini, peneliti memandang bahwa sebagai bentuk keterampilan produktif, pembelajaran keterampilan berbicara bahasa Indonesia membutuhkan perhatian dan pembiasaan untuk mengasah dan menumbuhkan kepercayaan diri siswa agar dapat berbicara dengan baik. Salah satu penentu keberhasilan proses dan hasil pembelajaran tersebut adalah guru. Guru yang berkompeten mampu menciptakan kondisi belajar yang nyaman, agar siswa lebih termotivasi dan bersemangat untuk mengikuti proses pembelajaran.

Hasil penelitian ini selaras dengan hasil penelitian-hasil penelitian sebelumya yang menyatakan bahwa pada hakikatnya pembelajaran keterampilan berbicara harus dilatihkan secara terusmenerus dan berkelanjutan untuk melatih siswa terampil berbicara dengan bahasa Indonesia yang berkarakter. Tanpa latihan yang berkelanjutan mustahil dapat diperoleh hasil pembelajaran yang membuat siswa mampu berbicara dengan bahasa Indonesia yang berkarakter. Hasil-hasil penelitian yang selaras dengan hasil penelitian ini dipaparkan berikut. Pertama, hasil penelitian Jilati Emba tahun 2007 yang intinya dikatakan bahwa pembelajaran berbicara dilakukan untuk melatih kemampuan bertanya dan menjawab pertanyaan. Siswa secara terus-menerus dilatih untuk terampil bertanya dan menjawab pertanyaan dengan santun, berkarakter, logis, dan efektif.

Kedua, hasil penelitian Mirhan Hasan Bumulo tahun 2008. Dikatakannya bahwa keterampilan berbicara siswa dapat ditingkatkan dengan menggunakan strategi Number Head Together (NHT). Peningkatan keterampilan berbicara siswa harus dibarengi dengan nilai-nilai karakter yang terintegrasi di dalamnya. Hal itu dimaksudkan semakin terampil siswa dalam berbicara akan semakin berkarakter pula gaya berbicaranya.

Ketiga, hasil penelitian Sumiyati Ismail tahun 2009. Hasil penelitiannya adalah tentang peran orang tua dalam upaya meningkatkan keterampilan berbicara siswa. Dijelaskan bahwa orang tua memiliki peranan sangat besar dalam meningkatkan keterampilan berbicara anaknya. Orang tua juga dapat mengintegrasikan secara efektif nilai-nilai karakter dalam mengajarkan anak-anaknya agar terampil berbicara. Perlu kerja sama antara orang tua dan guru dalam mendidik anak dalam berbicara. Di sekolah guru memberikan pelajaran, sedangkan di rumah orang tua membimbing anak belajar.

\section{SIMPULAN}

Berdasarkan hasil penelitian ini dapat disimpulkan dua hal berikut. Pertama, proses pembelajaran keterampilan berbicara bahasa Indonesia di SMK Negeri 1 Bulango Utara belum sepenuhnya berkarakter. Hal itu ditandai oleh adanya

Nilai-nilai Karakter dalam Pembelajaran Ketrampilan Berbicara Bahasa Indonesia pada Siswa SMK 
(a) interaksi antara guru dan siswa belum komunikatif, guru selalu menggunakan teknik bertanya untuk memancing siswa mau berbicara; (b) interaksi antara siswa dan siswa dalam pembelajaran cenderung bersifat santai. Hal itu dilihat dari penggunaan bahasa maupun cara siswa memberikan tanggapan atau menyanggah jawaban teman; (c) siswa yang aktif tampak mendominasi pembicaraan, sedangkan siswa yang pasif kurang berpartisipasi dalam pembelajaran; (d) dari delapan nilai karakter yang diterapkan dalam pembelajaran keterampilan berbicara bahasa Indonesia, nilai-nilai karakter yang selalu muncul adalah jujur, bertanggung jawab, percaya diri, ingin tahu atau cinta ilmu, dan menghargai orang lain. Sementara itu, nilai-nilai karakter yang intensitas kemunculannya kurang dalam setiap pembelajaran adalah bernalar (berpikir logis, kritis, kreatif, dan inovatif), santun, dan disiplin.

Di sisi lain, hasil pembelajaran keterampilan berbicara bahasa Indonesia di SMK Negeri 1 Bulango Utara mencakup hal-hal berikut (a) objektivitas pembicaraan.Bahasa siswa terpengaruh oleh bahasa asing atau gaul yang tidak efektif dan terkesan tidak santun; (b) kualitas isi pembicaraan.Isi pembicaraan Isi pembicaraan cenderung menonjolkan kehebatan bahasayang digunakannya dalam berdialog. Siswa memilih kata-kata yang muluk, bersifat trendi, namun tanpa arti; (c) sasaran atau arah pembicaraan. Penggunaan bahasa yang berbelit-belit namun tanpa arti tersebut menjadikan pembicaraan tidak tepat sasaran atau arah; dan (d) gaya berbicara.Terdapat variasi gaya berbicara siswa, seperti pelan dan malumalu, berbicara penuh semangat dengan menggerakkan anggota tubuh, dan ada juga siswa yang selalu mendominasi pembicaraan.

\section{UCAPAN TERIMA KASIH}

Artikel ini disarikan dari penelitian kolaborasi yang berjudul "Pembelajaran
Keterampilan Berbicara Bahasa Indonesia yang Berkarakter di SMK Negeri $1 \mathrm{Bu}-$ lango Utara, Kabupaten Gorontalo Tahun Pelajaran 2012/2013". Peneliti mengucapkan terima kasih kepada Kepala SMKN 1 Bulango Utara, Guru-guru Bahasa Indonesia SMKN 1 Bulango Utara, staf dosen Program Studi Pendidikan Bahasa dan Sastra Indonesia, Universitas Negeri Gorontalo dan semua pihak yang telah memberi masukan, komentar, kritik, dan dukungan yang sangat berharga. Semua kesalahan dan kekurangan yang terdapat dalam tulisan ini sepenuhnya adalah tanggung jawab penulis.

\section{DAFTAR RUJUKAN}

Afandi, R. 2011. "Intergrasi Pendidikan Karakter dalam Pendidikan IPS di SD". Jurnal Pedagogia, Volume. 1, Nomor. 1, hlm 85-101.

Bumulo, M.H. 2008. Meningkatkan Keterampilan Berbicara Peserta Didik melalui Pembelajaran Kooperatif NHT. Tesis tidak Diterbitkan. Gorontalo: UNG.

Devito, J.A. 1997.Komunikasi Antar Manusia. Diterjemahkan oleh Agus Maulana. Jakarta: Profesional Books.

Emba, J.2007. Kemampuan Bertanya dan Menjawab Pertanyaan dalam Pembelajaran Berbicara dengan Strategi Belajar Kooperatif Peserta Didik Kelas VIII SMP Negeri 6 Luwuk. Tesis tidak Diterbitkan. Gorontalo: UNG.

Fauzi, A.H. 2004.Psikologi Umum. Bandung: Pustaka Setia.

Ghazali, A.S. 2010.Pembelajaran Keterampilan Berbahasa: dengan Pendekatan Komunikatif-Interaktif. Bandung: Refika Aditama.

Ismail, S. 2009. Peran Orang Tua dalam Upaya Meningkatkan Keterampilan Berbicara Peserta Didik di SDN Oluhuta Kecamatan Kabila Kabupaten Bone Bolango. Tesis tidak Diterbitkan. Gorontalo: UNG. 
King, L. 2010.Seni Berbicara: Kepada Siapa Saja, Kapan Saja, di Mana Saja Diterjemahkan oleh Marcus Prihminto Widodo. Jakarta: Gramedia Pustaka Utama.

Kristiyani, A. 2014.“Implementasi Pendidikan Karakter pada Pembelajaran Bahasa di PG-TPA Alam Uswatun Khasanah Sleman Yogyakarta".Jurnal Pendidikan Karakter. Volume 4, Nomor 3, hlm250-265.

Miles, M. \& Huberman, A.M. 1992. Analisis Data Kualitatif: Buku Sumber Tantang Metode-Metode Baru. Jakarta:UI Press.

Mohidin, A.J. \& Napu, Y. 2011. Modul Assesmen. Gorontalo: Universitas Negeri Gorontalo.

Mulyana, D. 2001. Ilmu Komunikasi Suatu Pengantar. Bandung: PT Remaja Rosdakarya.

Musaba, Z. 2012.Terampil Berbicara: Teori dan Pedoman Penerapannya. Yogyakarta: CV. Aswaja Pressindo.

Pranowo. 2012. Berbahasa secara Santun. Yogyakarta: Pustaka Pelajar.
Semi, M.A. 2008. Terampil Berdiskusi dan Berdebat. Edisi Revisi. Bandung: Titian Ilmu.

Sudarsono. 2008. Kenakalan Remaja. Jakarta: Rineka Cipta.

Syafiie, I.K.2004. Pengantar Filsafat. Bandung: Refika Aditama.

Stubbs, S. \&Moss, S. 1996. Human Communication: Konteks-Konteks Komunikasi. Diterjemahkan oleh Deddy Mulyana. Bandung: PT Remaja Rosdakarya.

Tarigan, H.G. 2008.Berbicara sebagai Suatu Keterampilan Berbahasa. Edisi Revisi. Bandung: Angkasa.

Wahyuni, S. \& Ibrahim, A.S.2012. Perencanaan Pembelajaran Bahasa Berkarakter. Bandung: Refika Aditama.

Yamin, M. \&Ansari, B. 2012. TaktikMengembangkan Kemampuan Individual Siswa. Jakarta: Referensi.

Zulnuraini. 2012. "Pendidikan Karakter: Konsep, Implementasi dan Pengembangannya di Sekolah Dasar di Kota Palu". Jurnal Dikdas. Volume 1, Nomor 1, hlm 1-17. 